\title{
Kurt LAMPE, The Birth of Hedonism. The Cyrenaic philosophers and Pleasure as a way of life
}

\section{Ugo Zilioli}

\section{OpenEdition}

\section{Journals}

Electronic version

URL: https://journals.openedition.org/philosant/459

DOI: $10.4000 /$ philosant.459

ISSN: 2648-2789

\section{Publisher}

Éditions Vrin

\section{Printed version}

Date of publication: 24 November 2015

Number of pages: $269-276$

ISBN: 978-2-7574-1141-4

ISSN: 1634-4561

\section{Electronic reference}

Ugo Zilioli, "Kurt LAMPE, The Birth of Hedonism. The Cyrenaic philosophers and Pleasure as a way of life", Philosophie antique [Online], 15 | 2015, Online since 01 November 2018, connection on 03 December 2022. URL: http://journals.openedition.org/philosant/459; DOI: https://doi.org/10.4000/philosant.459

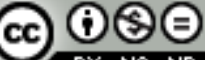

Creative Commons - Attribution-NonCommercial-NoDerivatives 4.0 International - CC BY-NC-ND 4.0 https://creativecommons.org/licenses/by-nc-nd/4.0/ 
Dialectique et réfutation ne concernent pas le soin de l'âme chez Aristote, mais sans doute vaut-il mieux réserver la pratique de l'elenchos aux membres de l'école ce que Platon suggérait déjà dans la République. S’il y a bien une continuité entre Socrate et Aristote, la démoralisation aristotélicienne de la réfutation signifie que pratiquer l'elenchos n'a plus aucun rapport avec l'examen de vie. Or, la dépersonnalisation de la dialectique est déjà à l'œuvre dans certains dialogues de Platon (République, Théétète, Sophiste, Philèbe, Parménide). Ainsi chez Platon, deux conceptions de la dialectique sont présentes et en concurrence. Aristote a très tôt rejeté pour sa part la dimention et le but éthiques de la dialectique socratico-platonicienne.

L'elenchos véritable est selon R. Bolton la réfutation peirastique des Réfutations sophistiques en ce qu'elle montre que la conviction particulière de celui qui est interrogé est en conflit avec des vérités communes. Aristote rejette l'idée selon laquelle la mise en contradiction établit l'ignorance. L'elenchos peirastique établit ainsi la fausseté d'une croyance par rapport à un ensemble d'autres. Or ce qui importe est le degré d'endoxicalité des convictions.

Dans le dernier chapitre, W. Kullman montre comment Aristote s'est progressivement détourné de la dialectique platonicienne en abandonnant la troisième fonction de la dialectique telle qu'elle est caractérisée dans les Topiques, à savoir la recherche des principes des sciences. Cet abandon est lié à ce que les Analytiques présentent comme une nouvelle procédure d'appréhension des principes, à savoir la perception, l'induction et l'expérience - à l'œuvre dans les écrits biologiques. La thèse de W. Kullman est convaincante concernant les écrits biologiques, mais ses affirmations, selon lesquelles les endoxa ne jouent aucun rôle dans le domaine de l'éthique et de la politique, résistent difficilement à la lecture des textes aristotéliciens - par exemple le livre I de l'Éthique à Nicomaque qui, pour définir le bonheur, va opérer tout un mouvement d'examen des endoxa sur l'eudaimonia avant d'en venir à la définition du bonheur à partir de l'ergon de l'homme, conformément à ce qu'Aristote énonce au début du livre VII (1145b2-7).

L'unité de ce livre est assurément le débat dialectique tel qu'il a été inauguré par Socrate et formalisé par Aristote. Et si d'un article à l'autre des thèses différentes, voire contradictoires peuvent être soutenues, tout friand de dialectique ancienne y trouvera de quoi se régaler.

Juliette LEMAIRE

Centre Léon Robin, CNRS/Paris-Sorbonne/ENS Ulm

Kurt LAMPE, The Birth of Hedonism. The Cyrenaic philosophers and Pleasure as a way of life, Princeton University Press 2015, XVII +277 p. ISBN: 9780691161136 (hardback; available also as an e-book)

The monograph by Kurt Lampe is the first systematic attempt in any modern language to deal with the ethics of the Cyrenaics, in particular with their hedonism. The book offers a detailed reconstruction of the ethical doctrines of both 
the Cyrenaics of the first generation (such as Aristippus the Elder, his daughter Arete, her son Aristippus the Younger) and the Cyrenaics of the later sects (such as Anniceris, Hegesias, Theodorus the Godless). After dealing with mainstream and later Cyrenaics, Lampe adds a chapter on the later reception of Cyrenaicism by Walter Pater, the nineteenth-century Oxford academic and novelist, thus making a case for the lively influence that Cyrenaic views had on subsequent hedonism. The book concludes with two very useful appendices, one dealing with the main sources on the Cyrenaics, the other discussing in details the most extended quotation on Cyrenaic doctrines we have, that is, Diogenes Laertius (II 86-93). For breadth of investigation, historical sensitivity and genealogical reconstruction, the book by Lampe represents an extremely valuable addition to the growing body of Cyrenaic scholarship.

Since the publication of Voula Tsouna's monograph on Cyrenaic epistemology in 1998 (The Epistemology of the Cyrenaic School, Cambridge, CUP), the Cyrenaics have continued to attract the attention of scholars, mainly in light of the philosophical appeal their views have on us. Recent years have witnessed the appearance of contributions (by, among others, Tim O'Keefe, James Warren, Christopher Rowe and, si parva licet, myself) dealing with all the most significant aspects of the philosophy of the Cyrenaics: their epistemological scepticism, the aprudentialism inherent to their ethics, the historical and conceptual linkage between their doctrines and the ones developed by the subtler thinkers in Plato's Theaetetus, the behaviourism implicit in their philosophy of language, the original metaphysical approach (or lack thereof) they seem to adopt (See e.g. T. O'Keefe, "The Cyrenaics vs. the Pyrrhonists on Knowledge of Appearances", in D. Machuca (ed.), Essays on Ancient Pyrrhonism, Leiden, Brill, 2011, 27-40; Id. "The Sources and Scope of Cyrenaic Scepticism", in U.Zilioli (ed.), From the Socratics to the Socratic schools, London, Routledge, 2015, 99-113; J. Warren, "Epicurus and the Pleasures of the Future", OSAP 21 [2001], 135-79; Id. "Cyrenaics", in J. Warren \& F. Sheffield (eds), The Routledge Companion to Ancient Philosophy, London, Routledge, 2014, 409-22; C. Rowe, "The first-Generation Socratics and the Socratic Schools: the Case of the Cyrenaics", in U.Zilioli (ed.), op. cit. 26-42; U.Zilioli, The Cyrenaics, London, Routledge, 2014; Id. "The Cyrenaics as Metaphysical Indeterminists", in U. Zilioli (ed.), op. cit. 114-132). But no exhaustive reconstruction of Cyrenaic hedonism has ever been attempted by anyone so far. The pioneering book by Lampe fills this gap. As he himself claims, "this volume therefore aims to be a complement to Voula Tsouna's monograph on Cyrenaic Epistemology, which is the most thorough investigation of Cyrenaic scepticism, and to help make a fuller appreciation of this 'original hedonism' available to classicists, philosophers, and cultural historians” (p. 3).

Lampe's monograph on Cyrenaic ethics could indeed be read as a proper complement to Tsouna's study. Differently from Tsouna, however, Lampe's book has no overarching argument to be taken as the main thesis the monograph has to 
offer to the scholarly debate. The monograph in fact reconstructs the ethical views of the Cyrenaics as these were variously developed by the different members of the school, without identifying a key philosophical concept subsuming all those views under the same pivotal idea (not even 'pleasure' or 'hedonism' do this work in Lampe's book, at least as far as I can tell). While Tsouna is 'analytical' in trying to sort out the main views and arguments around which the Cyrenaics constructed their doctrines, Lampe owes more to the 'continental' idea that the views held by a group of philosophers (or, for that matter, by a single philosopher) have to be understood by fully appreciating the historical context in which that group lived and worked. (In this Lampe is very sensitive to Michel Foucault's revelatory approach to ancient philosophy). With this remark, I do not wish to argue that one of the two approaches-either the analytical or the continental, to use two consumed labels that still retain some meaning to us-is right and the other wrong, or that adopting one of the two approaches means to be lacking either historical sensitivity or philosophical perspicuity. It is a matter of emphasis more than lack, and Lampe's emphasis is on the historical and genealogical side, more than on the exquisitely theoretical one.

Since Lampe's book does not have an overarching thesis, in this review I will provide a brief description of the main content of each chapter, such description being intertwined with critical remarks I offer as evidence of the stimulating effect that Lampe's book has on the mind of the interested reader.

The book has ten chapters and two appendices. In the Introduction, Lampe sums up the main contents of the book and sets out the methodology he adopts "to offer a robust and historically sensitive interpretation of Cyrenaic ethics as it functioned in Ancient Greece. Building up this historicized interpretation will occupy me for most of this book" (p. 7). At the same time, Lampe proposes to take a broader view of his historical approach by understanding Cyrenaic ethics "not as a set of beliefs and practices confined to a particular time and place, but as a framework for thinking and acting that can be filled out in different ways in different times and places" (ibid.). What Lampe does not aim to do is to defend the Cyrenaics and their views from their critics (see p. 8). By relying on Pierre Hadot's analysis, another important feature Lampe sees as deeply rooted into Cyrenaic thinking is the mixture of practices and doctrines that, according to him, are characteristic of the ethical approach of the Cyrenaics. As Lampe puts it: "we should be extremely sceptical that any Cyrenaic ever adheres to a significant ethical position because of the force of reasoning alone. The core positions of each school frame an existential option which is chosen for its positive features, i.e., the satisfying fit between the world it discloses and the inarticulate aspirations of his followers" (7).

In the second chapter ("Cyrene and the Cyrenaics: a historical and biographical overview"), Lampe offers a rather useful historical overview of the rich and flourishing city of Cyrene between the fifth century BC to the third century BC. 
In doing so, he fills in an important historical gap that proved to be particularly awkward for scholars, who before Lampe had to read the very informative but lengthy accounts of Chamoux, Laronde (in French) or even Thrige (in Latin). The overview of the history of Cyrene is integrated with biographical accounts of all the main philosophers who were held in antiquity to be Cyrenaic, from Aristippus the Elder, Arete and Aristippus the Younger, to Anniceris, Hegesias and Theodorus the Godless, including lesser-known members of the school, such as Aristoteles, Aristoxenus, Antipater, Epiteme, Parabetes, Aithops and Dionysius. Except for the two latter ones (one from Ptolemais, the other from Heraclea), all the members of the Cyrenaic school were originally from Cyrene. This may be good evidence that the Cyrenaic school had its main philosophical centre exactly in Cyrene. As Lampe remarks, it is wise to bear in mind that, alongside with the more influential schools of Plato and Aristotle, the Cyrenaics were an active group of thinkers who gained the philosophical scene just after the death of Socrates.

Chapters three ("Knowledge and Pleasure") is one of the chapters I have read with much interest, and the one on which I have more doubts. The main bulk of it deals with the epistemological foundation of Cyrenaic ethics. Lampe rightly recognizes that Cyrenaic epistemology provides the theoretical foundation within which the Cyrenaics constructed their ethics of pleasure and pain (p. 27). On two important aspects of Cyrenaic epistemology, I have found Lampe's analysis in need of further elaboration.

The kernel of Cyrenaic epistemology lies in the notion of 'pathos', which Lampe translates as 'experience'. The Cyrenaics appear to posit an epistemological gulf between the experiences we have and what causes them: we incorrigibly and unmistakably know our experiences (that is, that I taste as sweet the honey I am eating at the moment), while we cannot infer anything about the very cause of our experiences (that is, that the honey I am eating is really sweet). When they claim that we cannot really know the causes of our experiences, however, do the Cyrenaics think that I cannot know whether the honey I am eating is really sweet (as just suggested) or, more essentially, whether what causes an experience of sweetness in me is actually boney? That is, is the epistemological scepticism of the Cyrenaics about the epistemological properties of the honey, as Lampe in this study, Tsouna 1998 and Warren 2014suggest? Or is it about the identity of the honey as a particular object (O'Keefe 2015)? Or, even more radically, is such scepticism about the fact that there may be no actual reality for us to discover there (Zilioli 2015)? To dig deeper into such questions would have helped the reader to get a firmer grasp of some central aspects of the philosophy of the Cyrenaics, that is, of aspects that may have shed further light on their ethics too (especially when Lampe considers the 'experiences' (pathe) as the basis for the Cyrenaic theory of action, i.e. as the guides through which the Cyrenaics decide what actions are to be taken or avoided, p. $45 \mathrm{ff}$.). 
Another point that I think would have deserved more attention concerns the idea that the Cyrenaics could have accommodated within their epistemology a kind of second-order beliefs about 'experiences'. The thought that, in addition to (or building upon) 'experiences', Cyrenaic epistemology contemplates the role of second-order judgements provides us with an important revision of our understanding of that original and inspiring epistemology. Lampe sees the point and tackles it at pages 49-52, when he mainly discusses passages from Diogenes Laertius about Hegesias and his followers, and a relevant passage by Athenaeus. Yet, I find his overall discussion of this topic unsatisfactory, since it does not spell out clearly the main conceptual linkage he sees as operating between Cyrenaic 'experiences', 'appearances' and 'reasons'. Again, a more throughout analysis of this neglected part of Cyrenaic epistemology would have helped Lampe to provide a stronger basis for his claim that, in addition to pleasure, the Cyrenaics also had an ethics of virtue and that they valued such things as wealth, friendship, and education, and so on (that is, the sort of topics he discusses in chapters 4 to 6 ). The chapter ends with an illuminating discussion of the Cyrenaic concept of telos, understood both as the goal of one's life and as "the fullest, highest, most complete expression of whatever attributes the adjectives 'good', 'bad', and 'neither good nor bad' connote" (p. 53).

Chapters 4 to 6 deal very closely with the Cyrenaic ethics of virtue, with education and with happiness. In the first part of chapter 4 ("Virtue and Living Pleasantly") Lampe provides a detailed overview of Aristippus the Elder's concern for education and virtue, showing us how he cared for his entire life despite the emphasis he appears to have put on the experiences of the present. One of the main features of Cyrenaic 'experiences' is in fact that they are short-lived: for a Cyrenaic it is difficult to account both for what has already been and for what is just about to be. Cyrenaic presentism thus seems to trap the Cyrenaics into quite a serious ethical problem: how could they motivate a concern for their entire lives and for happiness if they relied exclusively on the perishing experiences of the present, among which pleasure ranks as the supreme one? Lampe provides two different yet overlapping answers to this question, one for Aristippus the Elder, another for mainstream and later Cyrenaics (who are fully dealt with in the second part of chapter 4). Aristippus' presentism is a sort of 'spiritual exercise' aimed "to reduce your anxiety, increase your sensitivity to pleasure, and sharpen your focus on making the best possible use of available resources" (p. 92). Similarly, the presentism of mainstream Cyrenaics has to be taken as a prudential rule of thumb: "the Cyrenaics advise against investing too much energy in planning for the future, preferring to follow Aristippus's example and trust their ability to adapt to whatever happens" (p. 92). Even Anniceris, whose re-formulation of the concept of telos may have well made him a full-blown anti-eudaimonist, is understood as caring for long-terms goals such as happiness (p. 88-91). 
Against much of current scholarship, with such answers Lampe reconciles Cyrenaic hedonism with eudaimonism and with an overall concern for long-term goals. If chapter 4 is the pars construens of Lampe's account to explain the Cyrenaic interest for happiness and long-term values, the brief chapter 5 ("Eudaimonism and anti-eudaimonism") is the pars destruens: here Lampe scrutinizes and rejects all the main explanations on whose basis the Cyrenaics are best understood as antieudaimonists and as not-caring for happiness (among such explanations there are those provided by Terry Irwin, Tim O'Keefe, James Warren and Fred Feldman). Chapter 6 ("Personal and Political relationships") is to be read in strict conjunction with chapter 4: Lampe shows how the concern for one's life intended as an entire, not-evanescing episode and for happiness makes the Cyrenaics interested in such values as friendship (the main topic of the chapter), benefaction, gratitude, enmity, patriotism, participation in political life. Lampe explores how these values were variously adopted and defended by Aristippus, mainstream Cyrenaics, Hegesias, Theodorus and Anniceris (pages 115-119 contain an excellent analysis of Anniceris' own position on friendship, as well as of the reasons for which his views may be taken as a substantial improvement of mainstream Cyrenaicism).

While I have learned much by reading chapters 4 to 6 , I also had an immediate reaction of mild surprise in seeing how Lampe accommodates happiness into the context of Cyrenaic hedonism. I am in full agreement with him in thinking the kind of hedonism as endorsed by the Cyrenaics to be perfectly compatible with a sort of eudaimonism. Yet, if one is genuinely a hedonist-and, as Lampe argues, the Cyrenaics were surely the first serious hedonists in the tradition of Western thought-one will have to conceive of happiness as a quite secondary, derivative aim in one's practical life. The ethical focus in the life of the hedonist is on pleasure, not on happiness. Given the sort of hedonism they appear to have endorsed, for the Cyrenaics the kind of pleasure that is the main focus of their ethical theory is actually the short-lived, unitemporal pleasure of the moment. The full acceptance of happiness into their ethics, therefore, has to be explained in light of the emphasis the Cyrenaics placed on pleasure. Lampe's own explanation seems to put both pleasure and happiness on almost the same level of importance in Cyrenaic ethics. Although he sees pleasure implicitly or explicitly always brought in in the way the Cyrenaics may have conceived of happiness, the explanation Lampe gives us to account for the concern the Cyrenaics showed for long-term values such as friendship, benefaction and so on becomes susceptible to be further reduced into an explanation leading us to embrace a theory that, at the end, will put happiness at its roots, not pleasure.

If this is so, the Cyrenaics will be understood as less straightforward hedonists than originally argued for in Lampe's book. But here I must confess that my own view on Cyrenaic eudaimonism (which I have developed to some extent in chapter seven of The Cyrenaics) may have prevented me from fully appreciating Lampe's 
own way to come to terms with the reasons why the Cyrenaics were hedonists with a concern for happiness. As Terry Irwin does (to refer to one of the scholarly accounts Lampe closely scrutinizes in chapter 5), one may well suggest that the Cyrenaics lacked a concept of the self as a stable and unitary item. Since they lacked that concept, their ethics cannot account for happiness, which itself requires a stable subject to be fully appreciated and enjoyed (this is, very roughly, Irwin's explanation of the Cyrenaics' rejection of happiness). The Cyrenaics seem not to have had an idea of the self either as a stable and unitary item (as Lampe's analysis seems to imply) or as something that is actually existent (see Irwin's analysis). But, if the Cyrenaics conceived of the self as a kind of loose entity that, $\dot{a}$ la Parfit, could account for psychological connectedness without offering any sort of personal continuity over time, one would be able to explain satisfactorily the interest the Cyrenaics showed for happiness while retaining the core of their original and fascinating hedonism.

Chapters 7 and 8 are Lampe at his best. In chapter 7 ("Hegesias's pessimism"), he discusses Hegesias, while in chapter 8 ("Theodorus's innovations") he deals with Theodorus the Godless. Both chapters are very welcome in so far as they both provide the first systematic attempt to deal with the views of these two shadowy figures of Cyrenaic thinkers. Shadowy how they may be, both Hegesias and Theodorus proved to be highly original philosophers in their own right and were highly regarded in antiquity. In chapter 7 Lampe focuses on Hegesias' pessimism by showing how it almost naturally grows out from the cornerstones of his ethics: indifference, magnanimity and autonomy. At the end, Hegesias' pessimism is depicted as a coherent and satisfactory theory of wisdom, a theory that Lampe sees as "more consistent than that of Socrates" (p. 146).

Theodorus the Godless was the most original thinker of the later Cyrenaic school. In his magisterial treatment of him, Lampe deals closely with the innovations he introduced into Cyrenaic philosophy: in Theodorus' opinion, joy and distress are to be taken as the ends of life; bodily pleasure and pain now become 'intermediates'. In addition, Theodorus was seriously interested in an ethics of virtues. Although he was by far the most revisionary among all the Cyrenaic philosophers, the view of wisdom he advocated has strong similarities with that of Aristippus: the wise man is the ethical measure of what has to be done or avoided. Theodorus' atheism is to be understood exactly in light of this conception of wisdom: together with other polemics, Theodorus uses his atheism to repudiate the consolidated system of positive laws and systematic ethics in which we all, more or less, live. The only criticism I have to level in this chapter is that Lampe does not make enough of the concept of 'indifference', which with 'self-sufficiency' he sees as central to Theodorus' thought. By trying a more positive approach towards Pyrrho's possible influence on Theodorus, as well as by relying less critically on Aldo Brancacci's pioneering article on indifference and indeterminacy ("Teodoro l'Ateo e Bione di Boristene fra Pirrone e Arcesilao", 
Elenchos 3 [1982], 55-85), Lampe could have provided a stronger philosophical outlook for some of the views he attributes to Theodorus (and to Hegesias too).

After having surveyed ancient Cyrenaicism, Lampe adds a chapter on the appropriation of Cyrenaicism on the part of Walter Pater (chapter 9: "The New Cyrenaicism of Walter Pater"), thus preferring to deal with the lively influence that Cyrenaicism had on subsequent hedonism than to focus on the ancient debate on the topic of pleasure, namely the debate between Epicureans and Cyrenaics (especially later Cyrenaics). The book ends with a brief conclusion ("Conclusion: the birth of hedonism") and two very instructive appendices, one providing a detailed account of all the main sources on the Cyrenaics and their thought ("Appendix 1: the Sources"), the other discussing a crucial passage in Diogenes Laertius (II 86-93), a passage where Lampe sees an Annicerean interpolation at work (“Appendix 2: Annicerean Interpolation in D.L. 2.86-93”). A lengthy bibliography and an index are also added.

Again, the book deserves to be widely read and is an extremely welcome addition to modern treatments of ancient hedonism. Even when you do not agree with it, Lampe's study works as a stimulus to re-work your own ideas in light of his exhaustive and refreshing handling of Cyrenaic ethics.

Ugo ZILIOLI

Université de Durham

B. Collette-DuČić et S. DelComminetTe (éd.), Unité et origine des vertus dans la philosophie ancienne, Bruxelles, Ousia, 2014 (Cahiers de philosophie ancienne), 478 p. ISBN 978-2-87060-171-6

Ce volume propose de retracer l'histoire des questions relatives à la théorie de l'unité et de l'origine des vertus dans la philosophie ancienne. Réunissant, pour la plupart, les contributions présentées lors d'un colloque organisé à l'Université libre de Bruxelles par le Groupe de philosophie ancienne du Centre de Philosophie, les 24 et 25 mars 2011, l'ouvrage, par l'ampleur de la période qu'il couvre, constitue une entreprise jusque-là inédite. Il propose une lecture qui ne prétend pas à l'exhaustivité, mais qui cherche «à fournir un panorama relativement complet des manières dont cette question a été abordée au cours d'une période déterminée de l'histoire, en couvrant la plupart des épisodes charnières de l'évolution de son traitement » (p. 17).

L'ouvrage s'ouvre sur un article de L.-A. Dorion, « L'introuvable unité des vertus dans les Mémorables de Xénophon » (p. 19-38), qui montre qu'on ne trouve chez le Socrate de Xénophon aucun équivalent des paradoxes dits de l'unité des vertus ou de la vertu-science. Toutes les vertus sont des formes de sophia, mais celle-ci se décline en autant de domaines de compétence susceptibles d'être connus. Il n'y a donc pas d'unité de la vertu chez Xénophon, car il n'y a pas d'unité de la sophia. 